\title{
Cities' Policies: the Work of European Cities to Counter Muslim Radicalisation
}

\author{
Anja van Heelsum ${ }^{1}$ (D) Floris Vermeulen ${ }^{1}$
}

Published online: 27 November 2017

(C) The Author(s) 2017. This article is an open access publication

\begin{abstract}
Intercultural relations might form the foundation for new developments and can stimulate energy in modern cities, but in some cases, these relations can also become the source of divergence and conflict. In the last decade, several European cities have been confronted with violent incidents related to some form of extremism. Some cities had to cope with violence by Muslim extremists, for instance Amsterdam, which dealt with the murder of Theo van Gogh. Other cities experienced violence from anti-immigrant or extreme-right movements, for instance London, where mosques were attacked. Radicalisation of small groups of immigrants or autochthonous people, who are distressed about intercultural relations, seemed to lie behind these incidents. Pressured by such events, some administrations in Europe developed policies. In this paper, we will discuss a number of examples of such local policies. We will discuss some programmes that we observed in cities that took part in our own fieldwork, the Cities Local Integration Policies (CLIP) project, which took place from 2007 to 2011 .. Our results show that both cities that do have de-radicalisation policies and cities that do not actually work on what phase theorists would call the breeding ground for radicalisation and on the final violent stage of terrorist acts. The difference between the two mainly lies in (not) addressing religious conservatism. We conclude the article with some remarks regarding this choice, also reflecting on the impact of the phase model supported at that time.
\end{abstract}

Keywords Muslim radicalisation · Extremism · De-radicalisation · Local policymaking City policy

Anja van Heelsum

a.j.vanheelsum@uva.nl

Floris Vermeulen

f.f.vermeulen@uva.nl

1 Department of Political Science, University of Amsterdam, PO Box 15578, 1001 NB Amsterdam, Netherlands 


\section{Introduction}

In the last decade, 'radicalisation' and 'terrorism' have become of increasing interest to local policy makers in European cities, provoked by high-profile violent events in which home-grown terrorists have played an important role, for instance in attacks in Madrid, London, Amsterdam and Paris. Local policy makers have become more aware of the potential threat of radicalised individuals than they were a decade ago (Buijs et al. 2006; Vermeulen 2014). Finding and discouraging so-called 'home-grown jihadists' (those who plan to join jihad fighters in Syria or Iraq and can come back and organise attacks in Europe) has been found to be increasingly relevant. Municipalities are also looking for measures to stop the assumed process of radicalisation and prevent people from becoming (more) radical. In 2009, most local policy approaches were based on the idea that radicalisation is a process with different phases in which individuals or groups increasingly develop more extreme ideological ideas (Moghaddan 2005; Slootman and Tillie 2006; Vermeulen and Bovenkerk 2012), even though there is no consensus in the scholarly debate about the existence of such process (De Goede, Simon and Hoijtink 2014). For instance, the question of to what extent non-violent extremism is a necessary phase leading to violent extremism remains unanswered (Bartlett and Miller 2012). Local policy makers, however, often feel pressured to formulate and implement policies intended to prevent individuals from radicalisation. Models that explain radicalisation as a process with phases provide a framework for local policy makers that allow them to act and intervene. In this paper, we are especially interested in the effect of the use (or lack of use) of such policies.

The central question of this paper is: how do policy makers in cities implement de-radicalisation policies to avoid radicalisation and violent extremism of Muslims in practice, and what are the main differences with cities without such deradicalisation policies? We leave aside the issue of whether or not radicalisation is actually a process, since others have extensively discussed this (see Buijs et al. 2006 for an overview). (The Cities Local Integration Policies (CLIP) project was initiated and funded by the European Foundation for Living and Working Conditions (Eurofound). More information: https://www.eurofound.europa.eu/clipeuropean-network-of-cities-for-local-integration-policies-for-migrants One of the authors was involved in the fieldwork in nine cities. But in the conclusion, we will reflect on what effect a process view on policy making might have had. As we will show, some policy makers think in these phases and have designed preventive measures as extracted from this policy analysis. The comparison between the four cities in three different countries as case studies allows us to see the extent to which an existing and encompassing radicalisation policy framework influences the formulation and usage of strategies by local policy makers. We show that cities that employ specific radicalisation policies and those that do not both implement preventive measures intended to target the presumed breeding grounds of radicalisation-segregation, isolation and discrimination - but that cities that employ radicalisation policies are more likely to address religious conservatism and to actively search for radicalising individuals. The outcomes of this comparison are important to understand not 
only how the implementation of radicalisation models works on a local level but also what is missing without such policies. This paper is not an evaluation of local policies (Gielen 2017), nor an inventory of best local practices, but a first step in understanding how local policies on radicalisation emerge and develop, as these types of policies have recently become increasingly important for urban bureaucrats.

\section{The CLIP Project}

Our data was gathered in 2009 in the context of the Cities Local Integration Policies (CLIP) project. The project had four modules between 2007 and 2011 with 20-35 cities as cases that had all implemented some policy practices on immigrants. In the 2009 module, 31 cities in 22 European countries participated (Heckman and Lücken-Klaßen 2010).

The selection of cities took place after a request in a meeting of the Council of the Regions for volunteers, which led to a first list. But after that, the diversity of countries had to be encouraged by active stimulation of specific cities by researchers and Eurofound staff. In many countries, there was one city, but in some two or maximum three.

After contact between the city and a research team had been established, a rather elaborate cooperation came about between one city official as a coordinator and one researcher. The responsible city official coordinated the search for information. He or she gathered information to fill in a questionnaire about the characteristics of the immigrant populations and with details of the national and local policies in the city. After this, a researcher visited the city for a week, to interview about 15 different representatives of policy makers, NGOs, migrant communities and other relevant stakeholders. After this, the researcher wrote a case study report about the city. All the cities' reports are in the same format (and are available on the Eurofound website). The CLIP project was not only meant for scientific data gathering on policy practices, but also for cities to exchange information on policies. Therefore, two conferences were held every year, with the researchers presenting their analysis, and city officials and other related or interested parties presenting and exchanging their policies.

From the 31 cities that took part in the 2009 module on intercultural relations, not many had policies on de-radicalisation at the time. We have taken two examples of cities with such policies, namely Amsterdam (Netherlands) and Kirklees (UK), and two examples where similar problems occurred but no deradicalisation policies were developed, namely Terrassa (Spain) and Breda (Netherlands).

The information that was gathered on the de-radicalisation policies came from both the questionnaires on the available policies and from researchers' fieldwork. The questionnaire contained questions about Muslim and extreme-right radicalisation, but only policies that deal with Muslim radicalisation will be treated below. Besides policy notes, as much extra information as possible was gathered around mosques, projects and relevant research by others in the city. The question why some cities chose to install de-radicalisation policies and others did 
not find them desirable or even refused to introduce them-counter to pressure from the national level—will be answered first.

\section{The Phase Model and the Policies that it Incites}

In the scientific literature, several models of the process of radicalisation have been developed, often involving phases from non-radical to extremist (Borum 2011; Buijs et al. 2006; Feddes et al. 2015; Moghaddam 2005; Sageman 2004; Schmid 2013; Silber and Bhatt 2007; Wiktorowicz 2004). Radicalisation is then considered as a dynamic but not per definition a linear process.

At the time of the CLIP project, a model designed by Slootman and Tillie (2006) had become popular among policy makers in the 31 participating European cities. This was partly due to presentations by officials from Amsterdam, who were working with this model, at the common CLIP conferences. The model was developed in 2006 to analyse the radicalisation process of Muslims and right- and left-wing extremists in Amsterdam, and then utilised to develop and implement preventive policies, mostly targeted at Muslim extremism. The authors merged and simplified the more complicated discussion and developed an easy-to-use model on the process of radicalisation that can be employed as a tool by policy makers to decide where to intervene. The model illustrates the view that the majority of a population is usually not radical, then a small section of the population develops into extreme thinkers based on some kind of ideology, and then an even smaller section proceeds to a phase in which they are in favour of violence, as displayed in Fig. 1.

We can detect four phases in the suggested process of radicalisation where policy makers can intervene. As the figure illustrates, the first phase is the moment that certain individuals withdraw from the large non-radicalised majority. For policy makers intervening in a potential breeding ground, this is therefore the first phase (phase I) where a de-radicalisation policy can become relevant. Then follows the search for an ideological reasoning. In the case of Muslim radicalisation, authors show that there is a move towards religious conservatism, in itself not dangerous unless it turns into a strong dislike of other religions. In this phase II, the city could try to intervene with the developing religious conservatism. In phase III, certain individuals are radicalised. The
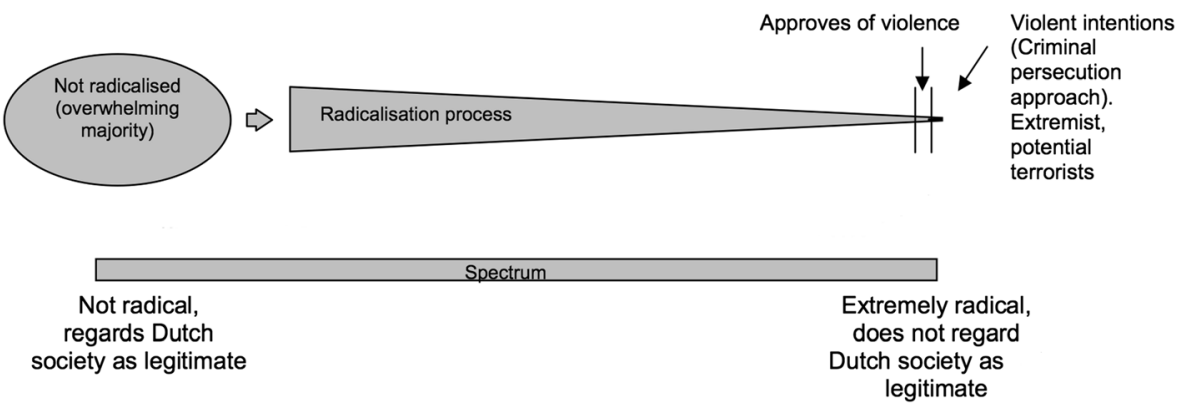

Fig. 1 Slootman and Tillie's model: the spectrum of not radical towards extremist. Source: Slootman and Tillie (2006:4, corrected) 
city can still implement policies to try and stop them. The last phase (IV) is intervention during or after the actual act of violence or terrorism.

Below, we will treat the phases in more detail, after first looking critically at the concept of a phase model. As already mentioned, from an academic perspective, the idea of radicalisation as a phased process and some of the assumptions in the model have met with serious criticism and discussion. Recent literature argues that the current models cannot fully explain why certain individuals become violent extremists (see for an overview King and Taylor 2011; Githens-Mazer 2012; Heath-Kelly 2012; Lynch 2013). This literature has distinguished a wide range of possible explanatory factors at the micro, meso and macro levels, but has not been able to explain the exact reasons for violent extremism or map causal linkages between explanatory factors and violent behaviour (Daalgaard-Nielsen 2010). It is difficult to describe, let alone define, any process of radicalisation exactly, or as Heath-Kelly posits (2012: 397):

Radicalisation is invoked by theory to serve a narrative that explains transitions to terrorism, much like the invocation of dark matter which is theorised into existence to fill holes in existing theoretical physics, but we should be cautious about assuming that the process necessarily exists.

Radicalisation might take place at an individual, group and macro level at the same time (McCauley and Moskalenko 2008). Psychological, social and political processes taking place simultaneously and in combination explain why individuals eventually engage in violent behaviour. The process can be chaotic, sometimes taking years, but there are also examples of it happening very fast, particularly among people who go through a shocking life event (Buijs et al. 2006).

A lot of this criticism of the phase model developed after policy makers implemented it, but this was not yet clear in the policy circuit in 2009. We will now look at the suggested phases in more detail, and see what kind of reasoning is behind every phase, in order to better understand how local policy makers intervene in accordance with the model.

Phase $I$ is the breeding-ground policies. Slootman and Tillie have suggested that policy makers have the first opportunity to react when certain people or groups show signs that they are on their way to abandoning the (not-radicalised) majority. These signs could be frustration and unhappiness, for instance caused by bad social conditions, dropping out of school, unemployment, and, in the case of Muslims, anger about Islamophobia and stereotypes concerning immigrants and Muslims. Psychological literature about people in insecure situations, who perceive exclusion and feel disconnected from society in general, shows that they could typically be inclined to 'turn their back on society' and look for an alternative group with extreme ideas. Perceived deprivation can - according to some authors - lead to a defensive reaction to fight unfair treatment (Moghaddan 2005:163). So, this inspired the idea that bad conditions could form a breeding ground for radicalisation.

Following the logic of the process view, a few individuals should be stopped from climbing Moghaddan's staircase and eventually getting recruited into a terrorist organisation. Addressing their grievances before it is too late is thus a logical policy step. Personal victimisation and political grievance are two of the potential mechanisms at 
the individual level (McCauley and Moskalenko 2008:418), so these could be addressed. For instance, both Muslim and extreme-right radical interviewees expressed the grievance that there is something fundamentally wrong and unfair in the way society functions, and they are the victims. Insecurity (negative) and idealism (positive) could be behind this, but in both cases, younger people are usually more prone to take extreme standpoints than older ones. Finding out which grievances they have and what insecurity/idealism is behind this is necessary.

Naturally, potential outcasts look for others who share their grievances. Halting the ingroup-outgroup categorisation that easily occurs in the minds of frustrated individuals who reinforce each other then becomes a relevant strategy, particularly halting the negative stereotyping of an outgroup (Tajfel and Turner 1979, 1986; Allport 1954). For instance, someone who is becoming more and more connected to a Muslim extremist grouping might become more hostile towards Christians or the dominant Christian culture in Western countries. After automatically defining the 'ingroup' (Muslims) more positively, the 'outgroup' (Christians) are painted with negative images, and generalisations become stereotypes. In the worst case, when a conflict extends, the outgroup members are described as 'wild' or 'strange' or sometimes as animals; that is, they are dehumanised (Staub 2006). ${ }^{1}$ Policy interventions that relate to this phase might be directed at discouraging susceptible individuals from getting to this disaffected state and/or blocking the step from general discontent to stereotypical and radical ingroupoutgroup thinking. In the results section, we will show examples of how the four cities in our study approach this.

Phase II is coping with religious conservatism. Religious conservatism is defined here by local authorities as a form of religion in which the person involved adheres to religious rules and regulations very strictly. He or she is not willing to have any kind of discussion about these rules and regulations and finds it increasingly difficult to function in an environment where others have other opinions and follow other value systems. For instance, a person feels it is impossible to work with colleagues of the opposite sex, which will hinder him or her in participating in the labour market. This is the step from general dissatisfaction to finding the 'solution' in a certain ideology such as religious conservatism or extreme scapegoating of a certain group. The radicalising person is thought to get more and more convinced that being a strict Muslim or an extreme nationalist is the solution to his or her problem, and maybe even to many other

\footnotetext{
${ }^{1}$ Staub (2005) argues that 'humanising the other' is a necessary step to solving (potential) conflicts. In the case of a city that faces negative views on Muslims, he suggests using the media to present the lives of Muslims in an understandable way, since knowledge about each other's needs helps the groups to understand each other and not to fear each other. The intention is to stimulate 'deep' contact, starting at schools and among youngsters, but also by arranging common activities, such as sport, business networks/collaborations or neighbourhood events.

Staub states that a second way to diminish conflicts is to promote a shared vision of a hopeful future through dialogue between Dutch and Muslim leaders. The involvement of Muslim religious leaders is crucial here. The dialogue includes fostering an inclusive and caring environment for children.

Thirdly, Staub thinks that in the case of Amsterdam, active involvement of members of the stereotyped minority groups in political debates will help to solve or prevent conflicts. Muslim representatives can express the needs of the immigrant communities. Furthermore, empowerment through engagement in constructive activities can help a lot, such as promoting positive leadership, helping influential individuals to take responsibility and seeing how they can exert influence by their words and actions in order to move their group.
} 
problems in the world, because he/she finds reassurance on websites and with similar thinkers.

For policy makers who are convinced that these kind of values are the underlying reason for radicalisation, intervention at this point is indispensable, since they see this as the core of the process. We should warn that the underlying assumption - that there has to be a religious transformation for Muslims to become extremists - is questionable. Some believers who become more strict may withdraw in a Sufi order, lead a peaceful life and are not a worry for policymakers. But most policy makers (on both the left and right) believe that certain extremists (for instance followers of IS) use Islam as a motive, and therefore in their eyes, this forms the core of the radicalisation process. Yet, many acknowledge that IS have a strange interpretation of religion and know that the majority of Muslims would object to violence as not 'real Islam'. When policy makers assume that religion is one of the key factors in the radicalisation process, they bump into the problem of the division of state and church and the (lack of) responsibility of the state in the religious sphere. It is not self-evident that the state claims influence on religious ideas. When trying to formulate policies, a discussion is stirred up on the rights (and limits to the rights) of authorities. As we will see, municipalities deal with this discussion in different ways. We will consider a number of policies in the results section that actually interfere in religious conservatism (step II).

Phase III in the policy model of Slootman and Tillie is to stop individuals or groups that have been identified as radical but that have not (yet) entered into the phase of planning or executing (political) violence. The aim at this point is to halt negative reasoning of individuals or potential group processes. Subgroup formation might have taken place, based on shared opinions such as 'society should not have allowed our exclusion', or 'the rules and laws in this society are not sufficient or maybe even wrong'. The policy should then attempt to channel collective criticism towards the existing system of rules and laws, before it develops into the vision that the laws are unfair or simply wrong and before the phase of de-legitimisation of the political system is reached-according to this model. This can advance further, with (some) individuals taking the law into their own hands. Such a process can be observed in the life histories of the right-wing extremists described by Linden (2009).

The last phase (phase IV), on the right-hand side of the spectrum in Fig. 1, is that the radicalised individual or group is planning or actually using violence. The policy interventions that deal with this fourth phase are related to police or security service efforts rather than regular social policy efforts by municipalities. As will become clear in the next section, some municipalities consider it their task to arrange preventive measures that are not exactly police work, for instance tracking potential terrorists to avoid the extreme damage they could potentially cause.

For policy makers, it is highly relevant to distinguish the moment and circumstances when negative attitudes transform into actual violent behaviour. But this is extremely difficult to predict. While a mild form of stereotyped thinking is common among most people, as a psychological mechanism to simplify the world is natural, a more extreme black-and-white reasoning might for some individuals cause the turn to violent action towards the 'outgroup'. Municipalities would like to know which individuals are most susceptible, but research outcomes are not consistent. In line with the tradition of Adorno, it has been suggested that people with certain personality characteristics are more prone to becoming violent and to losing a nuanced view of other groups, such as 
the authoritarian personality, which is a type of person inclined to black-and-white thinking (Adorno et al. 1950). But when trying to verify this for specific cases of radical individuals, Buijs et al. (2006) could not find systematic psychiatric problems among radical interviewees and suggested that — as with any psychiatric problem - there is an interaction with social circumstances.

From the literature on war-related trauma, we know that one specific negative experience can suddenly lead to a turning point in people's lives: the individual decides that enough is enough and that time has come to act. This turning-point experience is not necessarily related to an 'outgroup', but can be the death of someone close or redundancy, causing feelings of depression and then of anger or a crisis of identity (Feddes et al. 2015). The anger can get transferred to a person, or to an 'outgroup', who becomes the enemy (Doosje, Loseman and Bos 2013). This means that it is difficult for policy makers to identify the risk group. Spotting people who go through traumatic life events in the school or work context is probably only possible when they ask for help from a social worker, psychiatrist or doctor.

Spotting radicalisation among unemployed individuals seems the most difficult from a policy perspective, though unemployment in general is a reason for frustration, as addressed in phase I, the breeding ground. Linden (2009) mentioned that among right-wing extremists, the reasoning that immigrants have taken our jobs' is a justification for violence against immigrants. But municipalities seem to have few opportunities to spot specific people before violence has occurred.

In this paper, we want to show what kind of radicalisation policies have been implemented in some European cities and not in others, and why. The phase model will be used below to categorise the types of policies and also to better understand which elements are missing in the non-policy cities. This gives us the opportunity to critically discuss how relevant the different policy aspects in that model are for the desired outcomes.

\section{Results: the Policies in Four European Cities}

In this section, we turn to the results of the fieldwork in the cities and investigate the policy alternatives chosen at local level, following the four phases in the radicalisation process model mentioned earlier. It is interesting to see that some cities have a clearly outlined policy towards de-radicalisation such as Amsterdam (Netherlands) and Kirklees (UK), while other cities do not but have initiated very similar projects, as the examples of Terrassa (Spain) and Breda (Netherlands) show. Therefore, we will first give some details on the philosophy of the cities, and the reasons why they have addressed radicalisation or not. These philosophies are associated with cities' viewpoints on dealing with immigrants, religion and ethnic issues on the one hand and dealing with violence on the other. ${ }^{2}$

\footnotetext{
${ }^{2}$ A more elaborate analysis of the multicultural policies and religious policies in each of the cities is available in the city reports of the CLIP project (for Amsterdam see Van Heelsum 2010a; for Breda Van Heelsum 2010b; for Terrassa Van Heelsum 2010c; and for Kirklees Crawley and Crimes 2010).
} 


\section{The Four Cities' General Philosophies on Addressing Radicalisation or Not}

Two violent events in which Muslim extremists were involved triggered Amsterdam and Kirklees to address radicalisation. In Amsterdam, Theo van Gogh was murdered in 2004, and Kirklees was the home of terrorists involved in the London bombings of 2005. Both the Dutch and the British authorities launched a national campaign to stop the radicalisation of Muslims. In Amsterdam, the national policy line on radicalisation was embraced and even strengthened. Interestingly, although Madrid also experienced a terrorist attack in 2004, the Spanish authorities did not launch a similar campaign. The Zapatero government in power at that time in Spain stressed cross-cultural dialogue and understanding just after the attacks, while at the same time cautiously enforcing laws on violent behaviour (Archick et al. 2011).

Even when national policies gave direction, cities interpreted them in their own ways. Amsterdam developed a detailed philosophy with the key concept of social cohesionalready central in the Amsterdam approach - but now made suitable for conflict. The city invited the American professor in Conflict Studies Erwin Staub to analyse the problems behind the murder on Theo van Gogh (Amsterdam 2007, Van Heelsum 2010a).

The Dutch city of Breda disregarded the national policy to counter Islamic radicalisation. The national line of thinking was not considered helpful in coping with problems in Muslim communities as it was seen as too negative. Breda preferred to work with a 'diversity approach' formulated only in positive terms (Van Heelsum, 2010b).

Kirklees chose an explicit strategy and implemented elements of the national Prevent Plan on a local level. The Prevent Strategy uses the idea of a pyramid. Empowerment of local communities is one of the most relevant concepts in this case (Crawley and Crimes 2010):

'Communities must be at the centre of the response to violent extremism. We need to ensure that we foster community cohesion: building strong and positive relationships between people of different backgrounds, a sense of belonging and a shared vision for the future. Furthermore, strong, organised and empowered communities are better equipped to effectively reject the ideology of violent extremism, to confront and isolate apologists for terrorism, to channel legitimate grievances through democratic means and to provide support to vulnerable individuals' (Communities and Local Government Committee 2008).

In 2010, after our fieldwork, the UK Parliament criticised the Prevent Plan because the actual projects were difficult to distinguish from general integration projects for lower class and immigrant citizens, and did not directly address de-radicalisation (Archick et al. 2011). Therefore, the second Prevent Plan in 2011 was more specific; it mentions that vulnerable individuals might fall prey to extremist organisations, particularly if they feel that they are victims of racism and unfair treatment. The Home Office states that there is a lot of work that can be done by schools to avoid such developments (Home Office 2011).

In Spain, the national policy separates security and integration issues, according to our respondents. As one of the police officers explained in an interview, Spain considers ETA a more important terrorist threat than Muslims. Specific policies on religious groups were not considered desirable at the time of the fieldwork. In the Catalan city of Terrassa, de-radicalisation of Muslims is not directly addressed, and nor 
are Muslims as a category. The city chose the concept conviviencia as its central theme, which encompasses peaceful living together at the neighbourhood level as a basis for a pleasant, functioning, diverse society (Van Heelsum 2010c). There is a strong belief in Terrassa that all citizens_-immigrant or Spanish - are equal and should be treated equally, and therefore Terrassa's policy must address all inhabitants in the same manner.

\section{Policy Interventions in the Four Phases of the Radicalisation Process}

We will now show concrete examples of policies and projects in the four cities organised in line with the phases of Slootman and Tillie. We show what options city administrations have developed to work on de-radicalisation. The cities with explicit de-radicalisation policies, Amsterdam and Kirklees, did not choose to intervene at the same phase of the process. As we will show, cities without an explicit de-radicalisation policy sometimes have very similar policies, but they are framed more generally.

\section{Phase I: Breeding-Ground Policies}

Policies to diminish the breeding ground for radicalisation are intended to intervene at the moment that children, young people and adults are still part of the non-radical majority, with the intention of keeping them in that category. The factors that are thought to constitute a breeding ground for radicalisation are a polarised society with limited social cohesion and considerable media attention for extreme views, combined with personal problematic situations for youngsters. Feelings of unfair treatment, discrimination in the education system and labour market and isolation are some of the risk factors. Policy makers can decide where and how they want to intervene to diminish the risk of providing a breeding ground. Policy interventions may for instance focus on media, on social work or on the education of youngsters.

Activities that aim to diminish the breeding ground for radicalisation are meant to improve contacts between groups in general. Some examples of this in Kirklees are support for all kinds of community organisations, keeping contacts with mosques, organising mosque open days and supporting an interfaith network. Kirklees City Council finds inter-religious and intercultural dialogue of high importance (Crawley and Crimes, 2010).

Organising a festival with music and food during Ramadan is another way to invite non-Muslims to join an important Muslim celebration, so people can get to know each other better. In the Netherlands, a national 'Ramadan Festival' has been organised since 2005, which includes 4 weeks of varied programmes of cultural activities and iftars, meant to give the native population more insight into the fasting season of Muslims, and to perceive the Ramadan period as a common celebration for all.

These activities are explicit elements of the de-radicalisation policy in Amsterdam, but very similar things take place in Terrassa and Breda, albeit framed differently. In these latter, two cities, multi-cultural festivals are framed as a way to improve good social relations in neighbourhoods and stimulate mutual understanding. In the $\mathrm{Ca}$ n'Anglada neighbourhood of Terrassa, there is a festival on one of the squares where all kinds of (ethnic) food are shared and music is played.

As Staub suggested to Amsterdam, projects that focus on image formation and media can diminish ingroup-outgroup thinking, since mutual understanding can 
increase. The city therefore (co-)financed the production of the 'West Side soap', a drama series on a local TV channel about the lives of four families - one Turkish, one Moroccan, one Surinamese and one Dutch - that became neighbours. All kinds of themes such as love, discrimination, education, friends and work are dealt with. People are encouraged to find out more about each other's lives and cultures, but the story also shows how interconnected people in an arbitrary street in west Amsterdam already are. The aim is not only to show the experiences of people but also to fight prejudice, sometimes by dealing in a comical way with situations that easily lead to misunderstanding.

In the UK case, a report to the Home Secretary states that public figures and politicians have a responsibility not to demonise Muslims or (other) immigrants, as this could feed prejudice. Nevertheless, according to Lord Carlille, freedom of speech remains a key principle (Carlile, 2011).

Experiences of discrimination and prejudice are considered an important element of the breeding ground for radicalisation in the Dutch context. ${ }^{3}$ One of the frustrations that youngsters reported in our interviews in Amsterdam is that they think-due to prejudice - that their chances in the educational system, on the labour market and even on the streets are much lower than those of the (autochthonous) Dutch. An important activity for the city is thus to fight discrimination (Van Heelsum 2010a). Supporting the anti-discrimination office, or establishing one if it is missing in certain city districts, is therefore very important. The city launched a campaign with posters on the street with the message that discrimination is an offence and calling on victims to report it.

In the UK, laws against discrimination and regulations in favour of equal opportunities in the labour market are probably better developed than in most other European countries. The Race Relations Act prohibits discrimination based on race or ethnicity, and through the Racial and Religious Hatred Act hate crime is addressed. Furthermore, anti-discrimination programmes have been set up to work with young people in deprived areas, and better access of minorities to top universities is a goal (Archick et al. 2011:36-37). Recent budget cuts to these kinds of programmes have worried local councils. In the Kirklees report, the police are mentioned a few times as a source of frustration, while in the Dutch case the labour market was mentioned.

Anti-discrimination policies also exist in Breda and Terrassa, but without the explicit purpose of diminishing the breeding ground for radicalisation. In these two cities, the social situation of immigrants is also recognised as problematic, though not connected to the path into religious fanaticism or violence.

\section{Phase II: Coping with Religious Conservatism}

The second type of policies targets conservative religious views and values. Due to the principle of division between church and state, authorities do not easily interfere with religious issues. No policies on religion were found in Breda and Terrassa, but both

\footnotetext{
${ }^{3}$ Buijs et al. (2006) point to three factors: (1) the need for acceptance-if the subject perceives negative attitudes, he or she will have problems feeling accepted by the surrounding society; (2) meaning making; and (3) a sense of justice: if the subject perceives dissimilar treatment, for instance at school, on the labour market or by the police - regardless of whether this perception is justified or not-his or her chances of becoming radical increase.
} 
Amsterdam and Kirklees report interventions related to conservative Islam. In the perception of the interviewed staff of the municipality of Amsterdam, there is nothing wrong with religious conservatism in itself, as long as it does not lead to radicalisation. If people turn to conservatism out of frustration, or without nuanced information on what the grouping they are joining exactly want, there might be a problem. The reasoning in Amsterdam is that it is necessary to increase the 'resilience' of Muslim communities (Amsterdam 2007). Officials think that moderate mosques should be aware of the search that some members engage in and stimulated to act in providing them with information to judge religious websites and lecturers. In the interviews, it was mentioned that some older mosque representatives were at that time not aware of the type of information that young people could find on the internet, while it would be good if they could provide guidance on judging information found online, for instance about 'jihad' and how to treat 'kufar' (non-believers). Resilience means that the knowledge and ability to make informed choices increases and people are not drawn into a fundamentalist movement with false arguments. The first step for the municipality was in this case to raise awareness in the mosques and stimulate a proactive approach.

The local authorities in Amsterdam also support Muslim parents who are somehow insecure about their religious and cultural identity. This started after welfare offices and teachers noticed the needs of those parents. First-generation immigrants do not easily visit Dutch institutions because they feel misunderstood when the staff members of those institutions do not show cultural sensitivity. Many Turkish and Moroccan parents consider upbringing as a private issue, and feel easily ashamed when their child is 'difficult'. To give support in such situations, Amsterdam city district Slotervaart organised discussion meetings for parents in the secondary school in the neighbourhood, directed at 'cultural' aspects of upbringing, which could include religion (Slotervaart 2008: 14; Gielen 2008). Some youngsters think that their (Moroccan) parents follow a 'cultural' version of Islam that is not 'true Islam'. As the fieldwork of Gielen (2008) among strict girls shows, these girls interpret 'true Islam' as wearing a ghimmar (a long scarf, uncommon in Turkey and Morocco, which covers the head and shoulders and goes down to the hips), giving up a job at the supermarket because one has to scan wines, not accepting a job where one has to look men in the eyes or shake hands with them, no music, no birthday parties and even striving to have as little contact with non-believers as possible.

Encounters between social workers and parents showed that many parents worry about the religious aspect of upbringing. Situations that they have to cope with are for instance a daughter who has become extremely religious and who wants to wear a full chador, while her mother is moderate, and just wears a headscarf; the daughter is even telling her parents how to behave. The opposite kind of problem is a son who does not follow any Muslim rules, and causes shame by drinking alcohol during Ramadan, but is not following Dutch rules either. The parents do not always feel capable of discussing theoretical issues about Islam and see their children drifting in an unwanted direction without being able to stop them. The above discussion meetings are meant to address any kind of problem that is brought forward by parents, depending on their needs. Though the municipal effort is generally targeted at upbringing, a lot of the issues that were brought up in these meetings were related to religion. 
Besides supporting parents, the training of teachers can improve the overall potential of the community to support (second-generation) immigrant pupils. Helping teachers to be open to different cultural experiences and stimulate mutual understanding among pupils does not only create a good climate in the classroom, but also makes teachers capable of recognising boys and girls who get into problems, and to understand and support them. Teachers usually know their students well and might notice changes in their behaviour and their need for support.

Secondly, teachers deal with news items in the classroom, for instance concerning the Middle East. When Muslim students are angered by TV images of Palestinian suffering and convert this to a discussion on the enemies of Islam, for example, a classroom discussion can help to avoid overreactions and far-fetched conclusions. The teachers can decide to handle certain problems themselves, but for specific information can ask an expert. For instance, if the assumed obligation to defend fellow Muslims in Palestine and the ideology behind that needs to be discussed, it might be more effective to invite an expert, or to take the student to someone who is knowledgeable on Islamic theological issues.

As already mentioned, Muslim associations play an important role in increasing the resilience and information level of the community and the empowerment of youngsters. They help to raise the awareness of their members of different views on Islam, providing information and organising discussions on what strict Islam is and what moderate Islam is. A group of young Muslims opened what was called the Polder Mosque in Amsterdam where speakers from all the Islamic denominations and countries were invited with the intention to discuss these views. Even though the local district mayor reacted positively in the media, and this kind of awareness-raising among young Muslims was completely in line with policies, actual financial or other support for this initiative was seen as one step too far and was rejected by the city council. Soon afterwards, the mosque closed because of debts.

More indirect support for moderate ideas is more acceptable for a municipality. For instance in Kirklees, imams were encouraged in their effort to monitor information that was left in mosques and to destroy anything related to extremist ideology. Generally, municipalities consider it important to enhance the power of the existing and mostly moderate Muslim organisations and help them to support youngsters in their search for a good interpretation of Islam. A city administration cannot directly support activities with a religious content, but works indirectly. It is for instance possible to provide funding to organise meetings and question hours for general educational purposes, but always invite the imam to address religious questions. Having good relations with the Muslim organisations is then important.

Amsterdam gathered a group of active 'high potential' youngsters in an attempt to strengthen the internal resilience of Muslim communities. They were brought together from all relevant Muslim denominations in the 'Network of Key Figures'. Supporting 'Muslim Youngsters Amsterdam'-and thereby indirectly stimulating the network between the 'Union of Moroccan Mosques in Amsterdam' (UMMAO), the 'Council of Mosques' and the 'Polder Mosque'-succeeded to a certain extent. These active youngsters also participated in many of the discussion meetings. The group received training, but several proposals were at the time of the research waiting for permission from the local council, because they were too close to interfering with religion. 
A very original example of a project for Muslim youngsters in Amsterdam meant to increase resilience and stimulate empowerment at a personal level is the 'Socratic discussions project' (Slotervaart, 2008: 12). This took place in the El Ouma Mosque in Slotervaart in the west of the city, where the special imam for youngsters led discussions for those highly interested in religious issues. Basically, the imam presented all kinds of social questions and themes and asked the youngsters to reply. The central message was to be critical towards your source of information and take your responsibility as an individual in society. About 50 to 60 youngsters joined in the five meetings that were organised just before the summer holiday of 2008 (Gielen 2008). The discussion leaders clarified to us that these debates are particularly useful to break black-and-white thinking. The following example shows how this can work. A boy remarks: 'We cannot trust the Dutch. They are against Muslims!' The discussion leader replies: 'How did you conclude that?' The boy: 'Someone on TV said that Muslims are dangerous because they are all in jihad against the west'. The discussion leader 'Do you know what that means, jihad?' In this way a discussion develops in which the boy learns that jihad is not per definition violent and also concludes himself that people on TV sometimes do not know what they talk about. The discussion leaders experienced this method as more rewarding than just lecturing, since the discussions are often about values, and after a while, the students really learn to reason according to Islamic moral values.

Amsterdam installed another project to empower and train Muslim women in weak positions. The pilot 'Training Identity and Empowerment for Muslim girls' took place in the same district of Amsterdam, Slotervaart (Slotervaart 2008: 13; Gielen 2009a, b). Though at first it was a problem to convince girls to join such a training course, after some effort 16 girls started. They were part of a larger collective of 50 to 60 girls who were lectured by a woman on strict Islam and advice and guidance to women. They used the El Ouma Mosque, heard about the Socratic talks there, and thought they could profit from similar discussions. The girls were insecure about the Muslim/Moroccan and Dutch aspects of their identity. Six out of 16 finished the training and went through the following stages: (1) 'turning point': self-reflection, building up a positive selfimage, improving the ability to express thoughts and feelings, and solving problems; (2) 'moral judgement' - understanding how a moral judgement comes about, understanding how Dutch society developed with goals like freedom, prosperity and happiness and coping with religious dilemmas; and (3) conflict management: with parents, brothers and husbands. Though relatively few girls finished the training, the effect on those that did was enormous. Even those girls that stopped half way generally said that they were happier with themselves, their families and their surroundings after the course. They were better able to think critically and became active discussion partners in religious meetings.

Again, we see that a general measure to support youngsters is specifically used for Muslim youngsters, and in this case the focus is a reflection about oneself and about Islam. Another problem that this example shows is that it is extremely difficult to approach a group that might be at risk of radicalisation. These girls might not have become radical at all, and if this group was radical and had not used the mosque, the project staff would never have identified them. Similar groups probably meet in private homes. If the mosques had a broader reach towards these kinds of groups, it would be easier to spot and support them. 


\section{Phase III: Coping with Radical Individuals}

In the third phase of our model, an individual has turned their back on Western society. $\mathrm{He}$ or she is not just religiously conservative, but also no longer wants to be part of Western society. The biggest problem for local authorities is to find these individuals before they get to the violent stage. Amsterdam decided to set up a unit called the Radicalisation Information Unit, located in the city hall. Professionals from schools, youth work, police and city districts - all of whom are trained to recognise signs of radicalisation - can phone the Information Unit to make a report or to get advice. The office is in the Department of Public Order and Safety and has to function carefully in terms of the privacy of individuals.

If a case of actual radicalisation is confirmed, the notifier is usually told to seek cooperation from people around the individual or group. The earlier example already showed that it is not always easy to convince a potentially radical boy or girl to join courses. Therefore, the cooperation of imams, school teachers, youth workers, parents, family members and anybody who could be important is vital. Parents are informed about the views of their son or daughter and what this could imply. The strategy is to firstly address social problems: home, income, school, and mental and physical health. If possible, discussions between the boy/girl and a religious expert are set up. During this discussion - as with the Socratic discussions - reflection is stimulated, to unravel the consequences of someone's reasoning. Just by asking questions, a process of critical thinking is encouraged. For instance, the boy or girl is asked: 'would that mean that you would fight a war against your father?', 'would that mean that you would also kill your sister?', or 'do you think you are a good Muslim when you do this?'.

The Information Unit is relatively expensive, since the number of cases that it treats is limited. The municipality has to balance between avoiding one very serious incident and maintaining an expensive staff for nothing. In most cases, there are social problems. The most intensive form of intervention is required in no more than 8 or 10 cases per year. The chance of finding a psychiatric problem among this extreme group is considerable.

The other three cities did not report in the fieldwork on any search for and treatment of potentially radicalised individuals who have not committed any crime. They all speak of alertness in the Muslim community and the police, but leave any form of intervention to them.

\section{Phase IV: Dealing with Terrorism}

The last phase of the model is actual violent and terrorist acts. In a city, dealing with this is usually the remit of the police or the (national) security service. Police are sometimes locally and sometimes nationally coordinated, but the mayor is often in direct contact with the head of police. We will only mention the type of activities here that the cities can influence.

Examples of policies related to terrorism from CLIP cities show how social workers, educational workers, mosque officials and the police cooperate. In Amsterdam, this is institutionalised. Communication takes place at the central coordinating bureau of the municipality, the Information Unit. Individual cases end up here, and when the officers 
judge a case as being engaged or planning to engage in violent acts, it is transferred to the police, though close contact remains.

In Kirklees, police officers work closely with the West Yorkshire Counter Terrorism Unit. As Crimes and Crawley (2009:33) explain, 'this is a unit which gathers intelligence through both overt and covert methods. This intelligence is then assessed, evaluated, analysed and disseminated and is used to inform both police and security services about threats from groups and individuals regarding national security and domestic extremism issues'. Though the Unit works with partners in the Prevent Strategy, it remains rather separate from the community initiatives.

In Terrassa, there are direct contacts between one of the mosques and the police, though the city officials are not involved. These contacts were instigated just after the Madrid attacks, because mosque board members were suspicious about a travelling imam who wanted to preach in the mosque. Since that incident, a police officer drops by regularly to chat with the men in the mosque. The relaxed atmosphere in Terrassa enhances an easy information exchange. Something similar but more institutionalised happens in Breda, where a regular meeting between a safety coordinator and men from the mosque is held to exchange information. This small group can intervene if they foresee problems and can sometimes prevent a crisis.

\section{Conclusion}

In this paper, we have compared cities with explicit policies against Muslim radicalisation with those without such policies. We have organised the policies according to the phases that Slootman and Tillie (2006) had suggested and showed examples of the policies that have been implemented concerning the four phases.

Firstly, we will answer the question of how cities with de-radicalisation policies differ from cities without those policies. It strikes us that many of the projects in cities with an explicit de-radicalisation policy are not at all that different from those undertaken in cities that do not have such explicit policies. In the case of Terrassa for instance, most policies were carried out under the heading 'Conviviencia', which includes peacefully living together and sharing values, sharing a common idea about society and having similar ideas about the use of public space and a kind of public identity. The policies executed in Terrassa were actually quite similar to the policies to diminish the breeding ground of radicalisation in Amsterdam. Reacting against actual violent behaviour was in both cases left to the police, with structured contacts in the Netherlands, and informal ones in Spain. In that sense, having a clear policy framework in which different phases and explanations for radicalisation are provided does not seem to have a significant effect in the first and the last phase of the policies.

The differences between cities that do and do not have a de-radicalisation policy seem to lie in their involvement with religion itself - the second value-based phase suggested in the model. While Terrassa considers policy interventions in the religious sphere as completely impossible and Breda sees it as undesirable, in Amsterdam and Kirklees, there is a tendency to think that under certain conditions this mixture is possible and sometimes even desirable. In Amsterdam, a policy paper on this issue has been published as a guideline, which argues that it is necessary to differentiate between actual religious issues and cooperation on general social goals to target extremism and 
prevent people from entering into and progressing along the radicalisation process. The main purpose of this guideline is to enable cooperation with religious leaders and organisations, without state officials dealing with religious interpretations. Obviously, the problem of not strictly following the division between church and state is an issue that tends to come up in discussions among political representatives over and over again, making this type of preventive policy extremely difficult to implement. On the other hand, awareness within religious organisations and mosques has been triggered by the attempts, even though one cannot expect that they would be able to spot and prevent all radicalisation.

As said, since 2009, the importance of religion as a driver has been further questioned, and the view has taken hold that maybe it is not that Muslims radicalise, but radicals who already operate in a violent circuit Islamize. From that perspective, Islam is more of an excuse than the cause. However, that reasoning again assumes a process with a certain order and again assumes that religion plays a role. Whatever the order of events, we should conclude that religion should not be ignored, and mosques might be able to play the role as moderators and can help to point some of the searching youngsters in the right direction.

Overall, this study has given us the opportunity to bring together and describe deradicalisation policies in a logically organised manner, to critically look at the underlying principles, and give a first indication of the type of impact. The existence of an encompassing framework of a de-radicalisation policy mainly influences local policy makers in the field of religion, but interfering in religious issues remains highly problematic, and moreover there are doubts whether religious development is really that essential in the chain of processes. This fieldwork does not give a definitive answer to the question of whether a process view on radicalisation policies leads to better results. There is however little debate that what were called the breeding-ground policies - i.e. addressing discrimination and segregation including the messaging in the media - are important, as they fit in with local integration efforts and also address extreme-right radicalisation. The awareness that segregation and discrimination can lead to very serious frustrations remains an important lesson. Following the process view probably leads to an overemphasis on religion as a determinant factor. But as the above examples have shown, maintaining good relations with religious organisations and supporting youngsters in finding a suitable and non-violent religious middle ground is something a local government can and maybe should be striving for.

Open Access This article is distributed under the terms of the Creative Commons Attribution 4.0 International License (http://creativecommons.org/licenses/by/4.0/), which permits unrestricted use, distribution, and reproduction in any medium, provided you give appropriate credit to the original author(s) and the source, provide a link to the Creative Commons license, and indicate if changes were made.

\section{References}

Adorno, T. W., Frenkel-Brunswik, E., Levinson, D. J., \& Sanford, R. N. (1950). The authoritarian personality. New York: Norton.

Allport, G. W. (1954). The Nature of prejudice. MA: Reading.

Amsterdam (2007) Amsterdam tegen Radicialisering. Amsterdam: municipality policy document.

Archick, K., Belkin, P., Blanchard, C. M., Ek, C., \& Mix, D. E. (2011). Muslims in Europe: promoting integration and countering extremism. Washington: Congressional Research Service. 
Bartlett, J., \& Miller, C. (2012). The edge of violence: Towards telling the difference between violent and nonviolent radicalization. Terrorism and Political Violence, 24(1), 1-21.

Borum, R. (2011). Radicalization into violent extremism II: a review of conceptual models and empirical research. Journal of Strategic Security, 4(4), 37-62.

Buijs, F., Demant, F., \& Hamdy, A. (2006). Strijders van eigen bodem, radicale en democratische Moslims in Nederland. Amsterdam. Amsterdam: University Press.

Carlile, A. (2011). Report to the home secretary of independent oversight of prevent review and strategy. London: HM Government Resource document: https:/www.gov.uk/government/uploads/system/uploads/attachment_ data/file/97977/lord-carlile-report.pdf (accessed on 30 November 2015).

Communities and Local Government Committee (2008). Preventing violent extremism: next steps for communities. Resource document: http://webarchive.nationalarchives.gov.uk/20120919132719 /http://www.communities.gov.uk/publications/communities/pathfinderfund200708 (accessed on 30 November 2015).

Crawley, H., \& Crimes, T. (2010). Intercultural policies and intergroup relations-case study Kirklees. UK. Dublin: Eurofound Resource document: http://www.eurofound.europa.eu/sites/default/files/ef publication/field_ef_document/ef1038en4.pdf.

Dalgaard-Nielsen, A. (2010). Violent radicalization in Europe: what we know and what we do not know. Studies in Conflict \& Terrorism, 33(9), 797-814.

De Goede, M., Simon, S., \& Hoijtink, M. (2014). Performing preemption. Security Dialogue, 45(5), 411-422.

Doosje, B., Loseman, A., \& Bos, K. (2013). Determinants of radicalization of Islamic youth in the Netherlands: personal uncertainty, perceived injustice, and perceived group threat. Journal of Social Issues, 69(3), 586-604.

Feddes, A. R., Nickolson, L., \& Doosje, B. J. (2015). Triggerfactoren in het radicaliseringsproces. Den Haag/Amsterdam: Expertise Unit Sociale Stabiliteit/Universiteit van Amsterdam.

Gielen, A. J. (2008). Religie en cultuur in de (Marokkaanse) opvoeding. Evaluatie cursus opvoedingsondersteuning in Stadsdeel Slotervaart. Almere: A.G. Advies.

Gielen, A. J. (2009a). Een kwestie van identiteit. Evaluatie van de training Identiteit en Weerbaarheid voor Moslima's. Almere: A.G. Advies.

Gielen, A. J. (2009b). Uitgesproken meningen. Evaluatie van de religieus seculiere kring in Stadsdeel Slotervaart. Almere: A.G. Advies.

Gielen, A. J. (2017). Countering violent extremism: a realist review for assessing what works, for whom, in what circumstances, and how? Terrorism and Political Violence, 1-19 https://doi.org/10.1080 /09546553.2017.1313736.

Githens-Mazer, J. (2012). The rhetoric and reality: radicalization and political discourse. International Political Science Review, 33(5), 556-567.

Heath-Kelly, C. (2012). Counter-Terrorism and the Counterfactual: producing the 'radicalisation' discourse and the UK PREVENT strategy. The British Journal of Politics \& International Relations, 15 (3), 394 415.

Heckman, F., \& Lücken-Klaßen, D. (2010). Intercultural policies in European cities. dublin: Eurofound Online: http://www.coe.int/t/democracy/migration/Source/migration/congress_public_1.pdf.

Home Office (2011). The Prevent strategy 2011. Resource document: http://www.homeoffice.gov. uk/publications/counter-terrorism/prevent/prevent-strategy. (Accessed on 30 November 2015).

King, M., \& Taylor, D.M. (2011). The radicalization of home grown Jidhadists. A review of theoretical models and social psychological evidendence. Terrorism and Political Violence, 23, 602-622.

Linden, A. (2009). Besmet, Levenslopen en motieven van extreem-rechtse activisten in Nederland. Amsterdam: Vrije Universiteit.

Lynch, O. (2013). British Muslim youth: radicalisation, terrorism and the construction of the "other". Critical Studies on Terrorism, 6(2), 241-261.

McCauley, C., \& Moskalenko, S. (2008). Mechanisms of political radicalisation: pathways towards terrorism. Terrorism and Political Violence, 20, 415-433.

Moghaddan, F. M. (2005). The staircase to terrorism: a psychological exploration. American Psychologist, $60(2), 161-169$.

Sageman, M. (2004) Understanding terror networks. Philadelphia: University of Pennsylvania Press.

Schmid A.P. (2013). Radicalisation, de-radicalisation, counter-radicalisation: a conceptual discussion and literature review. The Hague: ICCT Research Paper 97. Resource document ICCT: https://www.icct. nl/download/file/ICCT-Schmid-Radicalisation-De-Radicalisation-Counter-Radicalisation-March-2013. pdf. Assessed on 14 November 2017.

Silber, M. D., Bhatt, A., \& Analysts, S. I. (2007). Radicalization in the west: the homegrown threat. New York: Police Department. 
Slootman, M. \& Tillie, J. (2006). Processen van radicalisering. Waarom sommige Amsterdamse moslims radicaal worden, Amsterdam: Gemeente Amsterdam/IMES. Resource document: https://pure.uva.nl/ws/files/732470/68728_Slootman_Rapport_processen_van_radicalisering_1_. pdf. Accessed on 14 November 2017.

Slotervaart (2008). Voorgangsrapportage Actieplan Slotervaart: het tegengaan van radicalisering. Amsterdam: policy paper city district Slotervaart.

Staub, E. (2006). Understanding the roots of violence, and avenues to its prevention and to developing positive relations between the local ethnic group and Muslim minorities in Amsterdam, in the Netherlands - and the rest of Europe. Paper. University of Massachusetts, Amherst. Published in 2007 in. Peace and conflict. Journal of Peace Psychology, 13(3), 333-362.

Tajfel, H., \& Turner, J. C. (1979). An integrative theory of intergroup conflict. In W. G. Austin \& S. Worchel (Eds.), The social psychology of intergroup relations. Monterey: Brooks-Cole.

Tajfel, H., \& Turner, J. C. (1986). The social identity theory of inter-group behavior. In S. Worchel \& L. W. Austin (Eds.), Psychology of intergroup relations. Chicago: Nelson-Hall.

Van Heelsum, A. (2010a). Intercultural policies and intergroup relations - case study: Amsterdam, the Netherlands. Dublin: Eurofound. Resource document: https:/www.eurofound.europa.eu/publications/case-study/2010 /netherlands/quality-oflife-social-policies/intercultural-policies-and-intergroup-relations-case-study-amsterdamthe-netherlands. Accessed on 14 November 2017.

Van Heelsum, A. (2010b). Intercultural policies and intergroup relations — case study: Breda, the Netherlands. Dublin Eurofound. Resource document: https://www.eurofound.europa.eu/publications/report/2010 /netherlands/quality-of-life-socialpolicies/intercultural-policies-and-intergroup-relations-case-study-breda-thenetherlands. Accessed on 14 November 2017.

Van Heelsum, A. (2010c). Intercultural policies and intergroup relations - case study: Terrassa, Spain. Dublin: Eurofound. Resource document: https://www.eurofound.europa.eu/publications/case-study/2010 /spain/quality-of-life-socialpolicies/intercultural-policies-and-intergroup-relations-case-study-terrassaspain. Accessed on 14 November 2017.

Vermeulen, F. (2014). Suspect communities - targeting violent extremism at the local level: policies of engagement in Amsterdam, Berlin, and London. Terrorism and Political Violence, 26(2), 286-306.

Vermeulen, F., \& Bovenkerk, F. (2012). Engaging with violent Islamic extremism: local policies in western European cities. Utrecht: FORUM.

Wiktorowicz, Q. (2004). Joining the cause: Al-Muhajiroun and radical Islam. Paper presented at the roots of Islamic radicalism conference. Cambridge: Yale University 8-9 May 2004. 